\author{
М. Михайлів, \\ кандидат юридичних наук, доцент, \\ доцент кафедри цивільного права та процесу \\ Львівського національного університету імені Івана Франка
}

\title{
ПРАВА ІНТЕЛЕКТУАЛЬНОЇ ВЛАСНОСТІ ЯК ОБ'ЄКТ МІЖНАРОДНИХ СПАДКОВИХ ВІДНОСИН
}

Міжнародні спадкові відносини за своїм характером $є$ складними, оскільки вони ускладнені певними формами іноземного елементу; завжди пов'язані з одним або кількома правопорядками, іншими, ніж український правопорядок. Об'єктом міжнародного спадкування $є$ права та обов'язки, що належали спадкодавцеві на момент відкриття спадщини і не припинилися внаслідок його смерті. Одним із видів прав, які можуть входити до складу спадщини, є права у сфері інтелектуальної власності.

Спадкування прав інтелектуальної власності в міжнародних приватних відносинах створює чимало питань і неоднозначних підходів до їх вирішення у правозастосовній діяльності. Це пов'язано із кількома чинниками, зокрема 3 відсутністю спеціальних положень про спадкування прав інтелектуальної власності в цивільному законодавстві держав; неуніфікованістю норм щодо спадкування прав інтелектуальної власності в спеціальних законах держав; незначною регламентацією цих питань в міжнародних договорах у сфері охорони прав інтелектуальної власності. Саме тому питання спадкування прав інтелектуальної власності в міжнародному приватному праві потребують дослідження та $є$ актуальними.

Питанням міжнародного спадкування прав інтелектуальної власності приділяли увагу низка українських та іноземних вчених: Н.Г. Вілкова, Г.В. Галущенко, І.Г. Гетьман-Павлова,
Г.К. Дмитрієва, К.О. Дубова, Ю.О. Заіка, Ю.М. Капіца, О.О. Кармаза, В.I. Кисіль, Л.А. Лунц, П.С. Нікітюк, О.А. Підопригора, А.А. Рубанов, Є.О. Рябоконь, A.A. Степанюк, Є.I. Фурса, С.А. Фурса, Г.В. Чурпіта, В.Ю. Чуйкова, А.Г. Хачатурян, О.I. Харитонова, Т.С. Хороша, Р.Б. Шишка та інші. Проте в науці ще залишається чимало питань, які потребують дослідження та $є$ актуальними.

Метою статті $є$ аналіз законодавства держав і міжнародних договорів у сфері спадкування прав інтелектуальної власності в міжнародному приватному праві, вивчення способів і засобів матеріального та колізійного регулювання міжнародного спадкування прав інтелектуальної власності, а також викладення власного бачення щодо удосконалення механізмів правового регулювання цих питань.

Уніфікований підхід щодо визначення поняття «інтелектуальна власність» міститься в ст. 2 Конвенції про заснування Всесвітньої організації інтелектуальної власності 1967 року. Відповідно до цієї конвенції інтелектуальна власність включає права, які стосуються літературних, художніх і наукових творів; виконавської діяльності артистів, звукозапису, радіоi телевізійних передач; винаходів у всіх областях людської діяльності; наукових відкриттів; промислових зразків; товарних знаків, знаків обслуговування, фірмових найменувань і комерційних позначень; захисту від недобросовісної конкуренції; всі інші права, що стосуються інтелектуальної 
діяльності виробничої, наукової, літературної і художньої сфер [6].

У міжнародному приватному праві виділяють дві категорії прав інтелектуальної власності. До першої належить авторське право та суміжні права, до другої - право промислової власності. Всі права інтелектуальної власності мають територіальний характер і підлягають правовій охороні відповідно до законодавства держави, на території якої вони були створені чи зареєстровані. Проте у відносинах в сфері права інтелектуальної власності з іноземним елементом виникають питання подолання територіального характеру таких прав.

Дієвим механізмом і способом подолання цієї проблеми є міжнародні договори у сфері охорони прав інтелектуальної власності. В міжнародних договорах дотримуються принципу територіальності, вони виступають єдиним способом подолання територіального характеру права інтелектуальної власності, оскільки їх завданням $€$ визнання і захист прав на результати творчої діяльності, що виникли в іноземній державі на підставі іноземного права.

Відповідно до ч. 3 ст. 3 Закону України «Про авторське право та суміжні права» суб’єктам авторського права i (або) суміжних прав незалежно від їх громадянства, твори чи об'єкти суміжних прав яких вперше оприлюднені на території іншої держави або не оприлюднені, але знаходяться в об'єктивній формі на території іншої держави, правова охорона надається відповідно до міжнародних договорів України [9].

Умови правової охорони винаходів (корисних моделей) визначені Законом України від 15 грудня 1993 року «Про охорону прав на винаходи i корисні моделі» (далі - Закон). Зокрема в ст. 6 цього Закону передбачено, що правова охорона надається винаходу (корисній моделі), який не суперечить публічному порядку, принципам гуманності і моралі та відповідає умовам патентоздатності.
Іноземні особи та особи без громадянства мають рівні з особами України права, передбачені цим Законом, відповідно до міжнародних договорів України, згода на обов'язковість яких надана Верховною Радою України. Іноземні особи та особи без громадянства, які проживають чи мають постійне місцезнаходження поза межами України, у відносинах з установою реалізують свої права через представників у справах інтелектуальної власності (патентних повірених), зареєстрованих відповідно до Закону. Якщо міжнародним договором України встановлено інші правила, ніж ті, що передбачені законодавством України про винаходи (корисні моделі), то застосовуються правила міжнародного договору, згода на обов'язковість якого надана Верховною Радою України (ст.ст. 4, 5) [10].

У ст. 5 Бернської конвенції про охорону літературних i художніх творів 1971 року (далі - Конвенція) передбачено, що автори творів, яким надається охорона на підставі цієї Конвенції, користуються в країнах Союзу, крім країни походження твору, правами, які надаються нині або будуть надані в подальшому відповідними законами цих країн своїм громадянам, а також правами, особливо наданими цією Конвенцією [2].

Відповідно до ч. 1 ст. 2 Паризької конвенції про охорону промислової власності від 20 березня 1883 року щодо охорони промислової власності громадяни кожної країни Союзу користуються в усіх інших країнах Союзу тими ж привілеями, які надаються нині чи будуть надаватися згодом відповідними законами власним громадянам, не обмежуючи при цьому прав, спеціально передбачених цією Конвенцією. Їх права будуть охоронятися так само, як і права громадян цієї країни, вони будуть користуватися тими ж законними засобами захисту від будь-якого посягання на ї права, якщо при цьому дотримуються умов та формальностей, приписуваних власним громадянам [8]. 
Спадкування прав інтелектуальної власності в міжнародному приватному праві відбувається у спосіб правонаступництва таких прав від спадкодавця до спадкоємців. На думку O.I. Харитонової, при спадкуванні виникають «вторинні правовідносини інтелектуальної власності у сфері творчої діяльності». Тому більш коректно вести мову не про «виникнення», а про «перетворення» або ж «трансформацію» творчих (авторських) правовідносин інтелектуальної власності, оскільки це точніше відображає сутність процесу, який при цьому має місце [13, с. 285]. Така трансформація має місце у випадку смерті автора при спадкуванні його прав.

Спадкодавцем прав інтелектуальної власності може бути як фізична особа, працею якої створено об’єкт права інтелектуальної власності, так i фізична особа, яка набула майнових прав інтелектуальної власності на підставах, передбачених законом. Такими суб'єктами можуть бути автор, виконавець, винахідник тощо.

Суб'єкти права інтелектуальної власності щодо створених ними об'єктів наділяються як майновими, так і немайновими правами. Зміст таких прав та їх оборотоздатність буде визначатися 3 урахуванням законодавства держави - місця виникнення такого права, а саме держави - місця створення твору, місця реєстрації прав інтелектуальної власності тощо.

Кожна держава самостійно визначає обсяг майнових i немайнових прав суб'єктів права інтелектуальної власності в спосіб закріплення їх у цивільних кодексах і спеціальному законодавстві у сфері інтелектуальної власності.

Відповідно до ст. 15 Закону України «Про авторське право і суміжні права» до майнових прав автора (чи іншої особи, яка має авторське право) належать: 1) виключне право на використання твору; 2) виключне право на дозвіл або заборону використання твору іншими особами.
Види особистих немайнових прав закріплені в ч. 1 ст. 14 цього Закону. До них віднесені такі права: 1) вимагати визнання свого авторства шляхом зазначення належним чином імені автора на творі і його примірниках i за будь-якого публічного використання твору, якщо це практично можливо; 2) забороняти під час публічного використання твору згадування свого імені, якщо він як автор твору бажає залишитися анонімом; 3) обирати псевдонім, зазначати i вимагати зазначення псевдоніма замість справжнього імені автора на творі i його примірниках i під час будь-якого його публічного використання; 4) вимагати збереження цілісності твору і протидіяти будь-якому перекрученню, спотворенню чи іншій зміні твору або будь-якому іншому посяганню на твір, що може зашкодити честі і репутації автора [9].

За сталими поняттями у $\in C$ до моральних прав автора належать:

- право бути визнаним автором твору («право творця»);

- право дозволяти або забороняти використання твору під справжнім іменем автора, псевдонімом або без зазначення імені, тобто анонімно («право на ім'я»);

- право вимагати збереження цілісності твору і протидіяти будьякому посяганню на твір, що може нанести шкоду честі, гідності та репутації автора («право цілісності») $[5$, с. 410].

Переважна більшість держав у своєму законодавстві передбачає можливість переходу від спадкодавця до спадкоємців лише майнових прав інтелектуальної власності. Особисті немайнові права інтелектуальної власності не залежать від майнових прав інтелектуальної власності та $€$ нерозривно пов'язаними із творцем (суб'єктом права інтелектуальної власності). У зв'язку з цим особисті немайнові права, які тісно пов'язані із творцем, не входять до складу спадщини. 
У доктрині щодо спадкування права інтелектуальної власності виділяють чотири концепції правонаступництва спадкоємцями творця: 1) до спадкоємців переходять і вони використовують у повному обсязі всі права інтелектуальної власності померлого автора; 2) у спадщину передаються виключно майнові права інтелектуальної власності, особисті немайнові права автора у спадкову масу не входять, хоча спадкоємці мають право захищати недоторканість твору; 3) право інтелектуальної власності переходить як певний комплекс особистих немайнових і майнових прав, обсяг яких вужче того, якими наділявся автор; 4) у спадщину переходять тільки ті права інтелектуальної власності, які виникли і не припинилися до смерті автора [7, с. 45].

Є.О. Рябоконь зазначає, що до складу спадщини поряд із майновими правами входять особисті немайнові права автора, які тісно пов'язані 3 майновими [12, с. 9]. Як зазначає K.О. Дубова, що стосується таких особистих немайнових прав автора як право авторства і право на ім'я, то не викликає сумніву, що вони не можуть належати іншій особі, крім самого автора, ні за його життя, ні після смерті [4, с. 448-453]. Тому вони $є$ природно невідчужуваними i не можуть бути переданими іншим особам.

Право авторства і право на ім'я тісно пов'язані 3 особою творця і в такому аспекті є вічними. Ці права мають самостійне значення і завжди забезпечуються правовою охороною, незважаючи на те, що в літературі розрізняють право авторства і авторство як соціальну цінність, перше з яких за загальним правилом припиняється зі смертю автора, а друге існує вічно [17, с. 110-121].

Погляди науковців щодо переходу у спадщину такого особистого немайнового права як права на недоторканість твору розійшлися. На думку одних авторів, спадкування цього права є не можливим взагалі [15, с. 15], інші вважають, що право на недоторканість твору включається до спадщини разом із майновими правами автора [11, с. 14].

Г. Чурпіта вважає, що право на недоторканість твору виникає 3 моменту створення твору, проте не припиняється після смерті автора [16, с. 24-27].

Право на недоторканість твору, яке належить живому автору, на думку К.О. Дубової, докорінно відрізняється від права на недоторканість твору, що належить спадкоємцям автора, оскільки автор має право змінити твір, внести в нього суттєві зміни, а спадкоємцям належить лише право забороняти іншим це зробити з метою збереження твору для суспільства в первісному вигляді. Звідси випливає, що право на недоторканість твору переходить до спадкоємців у неповному обсязі [4, с. 448-453].

Відповідно до ч. 4 ст. 423 ЦК України особисті немайнові права інтелектуальної власності не можуть відчужуватися (передаватися) за винятками, встановленими законом. Закон України від 23 грудня 1993 року «Про авторське право і суміжні права» в ч. 2 ст. 14 закріплює більш категоричний припис, відповідно до якого особисті немайнові права автора не можуть бути передані (відчужені) іншим особам. Більш конкретне правило передбачене ст. 29 Закону України «Про авторське право і суміжні права», в якій зазначено, що не переходять у спадщину особисті немайнові права автора.

Спадкоємці мають право захищати авторство на твір і протидіяти перекрученню, спотворенню чи іншій зміні твору, а також будь-якому іншому посяганню на твір, що може завдати шкоди честі та репутації автора. Проте право на такий захист спадкоємці зможуть реалізувати у випадку переходу до них права на охорону недоторканості твору, яке за своєю природою належить до немайнових прав. 
Тому пропонуємо виділяти два види немайнових прав автора: особисті немайнові права, які тісно пов'язані із творцем та є невід'ємними, а тому не можуть входити до складу спадщини та припиняються зі смертю автора; особисті немайнові права, які тісно пов'язані із майновими правами автора, що можуть входити до складу спадщини поряд із майновими правами інтелектуальної власності та сприятимуть у подальшому можливості спадкоємців здійснювати охорону та захист прав інтелектуальної власності спадкодавця.

Вважаємо, що 3 метою забезпечення охорони та захисту спадкоємцями прав інтелектуальної власності спадкодавця окремі немайнові права спадкодавця можуть входити до складу спадщини. Зокрема, це стосується такого особистого немайнового права як право на недоторканість твору. Проте зміст права на недоторканість носить зовсім інше смислове та змістовне навантаження, оскільки таке право переходить лише в обсязі, який надасть можливість спадкоємцям здійснити його охорону та захист.

Законодавство іноземних держав у сфері немайнових прав інтелектуальної власності істотно відрізняється. Насамперед це стосується самої назви таких прав. Так, у спеціальному законодавстві окремих іноземних держав можна зустріти такі назви немайнових прав як особисті права (Польща, Чехія, Нідерланди), нематеріальні права (Болгарія), моральні права (Велика Британія тощо).

Різним також $є$ зміст немайнових прав інтелектуальної власності в державах і строк дії таких прав. Так. У Болгарії, Ірландії строк дії немайнових прав дорівнює строку дії майнових прав, в Австрії, Нідерландах немайнові права автора захищаються лише протягом його життя, в Польщі, Литві, Чехії, Франції, Італії, Словаччині, Україні такий строк діє довічно, тобто такі права охороняються безстроково.
Відповідно до Бернської конвенції про охорону літературних і художніх творів (ст. 6bis) немайнові права, визнані за автором, зберігають силу після його смерті принаймні до припинення майнових прав і здійснюються особами або установами, уповноваженими на це законодавством країни, в якій витребовується охорона. Проте ті країни, законодавство яких у момент ратифікації цього акта або приєднання до нього не містить положень, що забезпечують охорону після смерті автора всіх прав, перелічених у попередньому пункті, можуть передбачити, що деякі з цих прав не зберігають сили після смерті автора [2].

У більшості держав немайнові права (особисті права, особисті немайнові права) не можуть бути передані іншим особам. Проте згідно з Авторським актом XIII Мальти після смерті виконавця його моральне право переходить до спадкоємців, якщо він про це зазначив у заповіті, а в іншому випадку - до осіб, яким було передано майнові права на виконання.

Після смерті автора охорона немайнових прав може здійснюватися різними особами, зокрема спадкоємцями за законом; спадкоємцями за заповітом; особою, на яку покладено управління спадщиною; спеціальним урядовим органом тощо. В окремих державах законодавство не визначає осіб, на яких може покладатися охорона особистих немайнових прав.

Відповідно до ч. 2 ст. 439 ЦК України в разі смерті автора недоторканність твору охороняється особою, уповноваженою на це автором. За відсутності такого уповноваження недоторканність твору охороняеться спадкоємцями автора, а також іншими зацікавленими особами [14].

Вважаємо, що така норма за своїм змістом не зовсім коректна та зрозуміла. Насамперед не зрозумілим є те, кого необхідно відносити до кола зацікавлених осіб, кого необхідно відносити до кола уповноважених осіб. Мабуть, законодавець мав на увазі 
спадкоємців за заповітом. У зв'язку 3 цим пропонуємо ч. 2 ст. 439 ЦК України викласти в новій редакції: «У разі смерті автора недоторканність твору охороняється спадкоємцями за заповітом. За відсутності такого уповноваження недоторканність твору охороняється спадкоємцями за законом. У випадку відсутності заповіту, неприйняття спадщини спадкоємцями за законом або за заповітом чи відсутності спадкоємців за законом недоторканність твору охороняється установою, яка забезпечує формування та реалізує державну політику у сфері інтелектуальної власності».

Важливою умовою переходу майнових прав інтелектуальної власності при спадкуванні в міжнародному приватному праві $є$ чинність таких прав на момент смерті спадкодавця. Строк чинності майнових прав кожна держава визначає по-різному. Такі строки відрізняються, виходячи з видів прав інтелектуальної власності. Так, відповідно до ст. 28 Закону України «Про авторське право і суміжні права» авторське право на твір виникає внаслідок факту його створення і починає діяти від дня створення твору. Авторське право діє протягом усього життя автора і 70 років після його смерті, крім випадків, передбачених цією статтею [9]. Обчислення строку діï авторського права після смерті автора починається від дня смерті автора і відлічується 31 січня року, наступного за роком смерті чи роком, у якому відбулася зазначена подія.

Для творів, оприлюднених анонімно або під псевдонімом, строк дії авторського права закінчується через 70 років після того, як твір було оприлюднено. Щодо творів, створених у співавторстві, такий строк встановлюється протягом 70 років після смерті останнього співавтора. Авторське право на твори посмертно реабілітованих авторів діє протягом 70 років після їх реабілітації. Авторське право на твір, вперше опублікований протягом 30 років після смерті автора, діє протягом 70 років від дати його правомірного опублікування [9]. Проте необхідно звернути увагу і на те, що у вище перерахованих випадках обчислення строку авторського права буде пов'язуватися із днем настання події та буде відлічуватися з 1 січня року, наступного за роком смерті, чи роком, у якому відбулася зазначена подія.

На відміну від майнових авторських прав, строк дії майнових прав виконавців охороняються протягом 50 років від дати першого запису виконання. До спадкоємців виконавців і правонаступників виробників фонограм і відеограм та організацій мовлення переходить право дозволяти чи забороняти використання виконань, фонограм, відеограм, публічні сповіщення, а також право на одержання винагороди у межах встановленого строку.

Відповідно до Бернської конвенції про охорону літературних i художніх творів 1971 року термін охорони становить увесь час життя автора i 50 років після його смерті, а обсяг охорони, як i засоби захисту, що забезпечують автору охорону його прав, регулюються виключно законодавством країни, в якій виникає потреба в ній. Охорона в країні походження регулюється внутрішнім законодавством. Проте, якщо автор не $є$ громадянином країни походження твору, відносно якого йому надається охорона на підставі цієї Конвенції, він користується в цій країні такими ж правами, як і автори-громадяни цієї країни. Під країною походження в Конвенції розуміється:

- для творів, вперше випущених у світ в будь-якій країні Союзу, - ця країна;

- для творів, випущених у світ одночасно в кількох країнах Союзу, що надають різні терміни охорони, та країна, законодавство якої встановлює найкоротший термін охорони;

- для творів, випущених у світ одночасно в будь-якій країні, що не

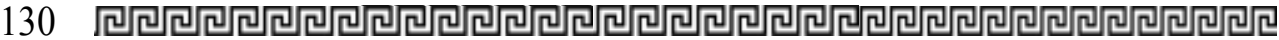


входить до Союзу, і в одній із країн Союзу, - остання країна;

- для творів, не випущених у світ, або для творів, випущених у світ вперше в країні, що не входить до Союзу, без одночасного випуску в світ у будь-який країні Союзу, та країна Союзу, громадянином якої $€$ автор, за умови, що відносно кінематографічних творів, виробник яких має свою штаб-квартиру або звичайне місце проживання в якій-небудь країні Союзу, країною походження є ця країна; відносно творів архітектури, споруджених у будь-якій країні Союзу, або інших художніх творів, що $є$ частиною будівлі чи іншої споруди, розташованої в будь-якій країні Союзу, країною походження є ця країна [2].

Отже, Бернська конвенція з питань охорони та захисту авторських прав закріпила колізійну прив’язку «право держави, в якій виникає потреба в охороні чи захисті авторських прав». На думку І.Г. Гетьман-Павлової, запропоноване в Бернській конвенції формулювання породжує проблему трактування поняття «країна, в якій виникає потреба в охороні» (lex loci protectionis). Цей термін, на ii думку, може застосовуватися і до держави, суд якої розглядає справу, і до держави, в якій правоволоділець бажає отримати захист, і до держави, на території якої були порушені авторські права. Норма Конвенції не визначає юрисдикцію, не вказує, що держава, яка надає охорону, - це держава, на території якої «запитується» охорона [3, с. 404].

Колізійне регулювання прав інтелектуальної власності здійснюється лише в декількох юрисдикціях, зокрема, в Угорщині, Португалії, Румунії, Італії, Швейцарії, Польщі, Тунісі, Україні, Ліхтенштейні тощо. Проте така національна кодифікація держав здебільшого регулює окремі аспекти права інтелектуальної власності і пов'язується із захистом таких прав. У сфері спадкування прав інте- лектуальної власності колізійні норми відсутні.

Різний підхід у законодавстві держав до видів прав інтелектуальної власності, ї змісту, правонаступництва таких прав та їх охорони призводить до ускладнення міжнародного спадкування прав інтелектуальної власності. Це вказує на потребу вироблення уніфікованого підходу до колізійного регулювання питань спадкування прав інтелектуальної власності в законах про міжнародне приватне право. Зокрема, це стосується визначення права, яке буде застосовним до питань можливості спадкування тих чи інших видів прав інтелектуальної власності; віднесення тих чи інших прав інтелектуальної власності до майнових чи немайнових прав; віднесення їх виключно до прав автора чи прав інших суб'єктів права інтелектуальної власності; визначення строку охорони таких прав; визначення права, яке буде застосовуватися щодо захисту спадкоємцями прав інтелектуальної власності творця (спадкодавця) тощо.

Також пропонуємо доповнити Закон України «Про міжнародне приватне право» статтею «Здійснення прав інтелектуальної власності» та викласти іiі в такій редакції: «До питань здійснення прав інтелектуальної власності, а також віднесення прав інтелектуальної власності до майнових чи немайнових прав, застосовується право держави, на території якої право інтелектуальної власності виникло, зокрема у сфері авторського права - право держави, на території якої такий твір був створений (якщо твір не був опублікований, то застосовується особистий закон автора); у сфері суміжних прав - право держави, на території якої таке право було вперше здійснено або вироблено; у сфері промислової власності - право держави місця реєстрації майнових прав.

Строк та обсяг охорони прав інтелектуальної власності визначається правом держави, на території 
якої право інтелектуальної власності виникло. Для творів, випущених у світ одночасно в кількох державах, що надають різні терміни охорони, охорона прав інтелектуальної власності буде здійснюватися відповідно до права держави, яка встановлює найкоротший термін охорони. Для творів, випущених у світ одночасно в кількох державах, строк та обсяг охорони прав інтелектуальної власності визначатиметься відповідно до права останньої держави. Для творів, не випущених у світ, строк та обсяг охорони прав інтелектуальної власності визначається особистим законом автора. Строк та обсяг охорони творів архітектури або інших художніх творів, які $€$ частиною будівлі чи іншої споруди, визначається правом держави місця знаходження таких об'єктів.

Також не вирішеним є питання, пов'язане з тим, до кого переходять права інтелектуальної власності у випадку відсутності спадкоємців або відмови спадкоємців від спадщини. У доктрині $з$ цього питання висловлювалися різні позиції, наприклад, у випадку відсутності спадкоємців такі права припиняють свою дію або, виходячи з правил, встановлених ЦК України, переходять до територіальної громади як відумерла спадщина.

На думку Г. Чурпіти, твір переходить у суспільне надбання не тільки після спливу строку чинності майнових прав на нього, але й у випадку відсутності спадкоємців [16, с. 303]. Вважаємо, що перехід у суспільне надбання пов'язаний лише із закінчення строку дії авторського права на твори, у зв'язку з чим не пов'язаний із правонаступництвом у випадку відсутності спадкоємців чи у випадку їх відмови від прийняття спадщини. У зв'язку зі специфікою об'єкта спадщини вважаємо, що права інтелектуальної власності повинні в цьому випадку переходити до установи, яка забезпечує формування та реалізує державну політику у сфері інтелек- туальної власності. Тому охорону прав інтелектуальної власності як протягом строку дії таких прав, так і після переходу у суспільне надбання повинно бути покладено саме на цю установу.

Стаття присвячена дослідженню питань міжнародного спадкування прав інтелектуальної власності. Звертається увага на те, що дієвим механізмом подолання територіального характеру прав інтелектуальної власності $є$ міннародні договори, завданням яких $\epsilon$ визнання $і$ захист прав на результати творчої діяльності, шо виникли в іноземній державі на підставі іноземного права.

Акцентується увага на тому, що кожна держава самостійно визначає обсяг майнових і немайнових прав суб'єктів права інтелектуальної власності в спосіб закріплення їх у циивільних кодексах, спеціальному законодавстві у сфері інтелектуальної власності та передбачає можливість переходу таких прав шляхом правонаступництва до спадкоємиів.

Переважна більшість держав у своєму законодавстві передбачає можливість переходу від спадкодавия до спадкоємиів лише майнових прав інтелектуальної власності. До переходу особистих немайнових прав інтелектуальної власності до спадкоємиів законодавство різних держав підходить неоднозначно.

У доктрині погляди науковиів з питань можливості правонаступництва немайнових прав інтелектуальної власності розходяться. У зв'язку з ицм запропоновано виділяти два види немайнових прав автора: особисті немайнові права, які тісно пов'язані із творцем та є невід'ємними, а тому не можуть входити до складу спадщини та припиняються зі смертю автора; особисті немайнові права, які тісно пов'язані із майновими правами 
автора, що можуть входити до складу спадщини поряд із майновими правами інтелектуальної власності та сприятимуть можливості спадкоємців здійснювати охорону та захист прав інтелектуальної власності спадкодавия.

Не вирішеним є питання, пов'язане з тим, до кого переходять права інтелектуальної власності у випадку відсутності спадкоємців або відмови спадкоємців від спадщини. У зв'язку зі специифікою об'єкта спадщини вважаємо, що права інтелектуальної власності повинні в цьому випадку переходити до установи, яка забезпечує формування та реалізуе державну політику у сфері інтелектуальної власності.

У статті звертається увага на mе, що різний підхід у законодавстві держав до видів прав інтелектуальної власності, їх змісту, правонаступництва таких прав та ix охорони призводить до ускладнення міжнародного спадкування прав інтелектуальної власності. У зв'язку з иим виникає потреба в міжнародній і національній уніфікаиії норм у сфері спадкування прав інтелектуальної власності та гармонізації законодавства держав.

Ключові слова: спадкування, міжнародне спадкування, об’єкт спадкування, права інтелектуальної власності, охорона прав інтелектуальної власності, майнові права автора, колізійне регулювання.

Mykhailiv M. Intellectual property rights as an object of international inheritance relations

The article is devoted to the analysis of international inheritance of intellectual property rights. It is emphasized that an effective mechanism for eliminating of the territorial nature of intellectual property rights are international treaties, aiming at the recognition and protection of rights to the results of intellectual activities that have emerged in a foreign state on the basis of foreign law.

It is highlighted, that each state, on its own, determines the scope of property and non-property rights of intellectual property rights by enshrining them in civil codes and special legislation in the area of intellectual property and provides for the possibility of the transfer of such rights by their succession to the heirs. The majority of states in their legislation provides the possibility of transfer from the testator to the heirs only intellectual property rights.

Regarding the transfer of personal non-property intellectual property rights to heirs, the legislation of different states is ambiguous. In the doctrine, the views of scholars on the possibility of succession of nonproperty intellectual property rights are slightly differ.

In this regard, it is proposed to distinguish two types of nonproperty rights of the author: personal non-property rights, which are closely related to the creator and are inalienable, and therefore cannot be part of the inheritance and ceased with the death of the author; personal non-property rights, which are closely related to the property rights of the author, which may be part of the inheritance along with intellectual property rights and will further enable the heirs to protect and defend the intellectual property rights of the testator.

The issue concerning the person to whom the intellectual property rights are transferred in the case of the absence of heirs or the heirs' refusal to inherit seems to be still unresolved. Due to the specifics of the heritage object, we believe that intellectual property rights should in this case be transferred to the Institution that ensures the formation and implementation of state policy in the field of intellectual property. 
The article draws attention to the fact that the different approach in the legislation of states to the types of intellectual property rights, their content, succession of such rights and their protection leads to the complication of the international inheritance of intellectual property rights. In this regard, there is a need for international and national unification of norms regarding the inheritance of intellectual property rights and harmonization of state legislation.

Key words: inheritance, international inheritance, object of inheritance, intellectual property rights, protection of intellectual property rights, property rights of the author, conflict regulation.

\section{Література}

1. Актуальні проблеми спадкового права : навч. посіб. Київ : КНТ, ЦУЛ, 2014. 336 c.

2. Бернська конвенція про охорону літературних $i$ художніх творів віо 24 липня 1971 року. URL: https:// zakon.rada.gov.ua/laws/show/ 995_051\#Text.

3. Гетьман-Павлова И.В. Международное частное право : учебник. Москва: Эксмо, 2009. 704 c.

4. Дубова К.О. Немайнові права авторів: аспекти міжнародно-правової регламентації. Держава $і$ право: Юридичні $i$ політичні науки. 2006. Bun. 31. C. 448-453.

5. Капіияа Ю.М. Авторське право $i$ суміжні права в Європі : монографія. Київ : Логос, 2012. 696 c.

6. Конвенція про заснування Всесвітньої організації інтелектуальної власності від 14 липня 1967 року. URL: https: / / zakon.rada.gov.ua/laws/ show/995_169\#Text (дата звернення: 14.07.2020).
7. Никитюк П.С. Наследственное право и наследственный процесс: проблемы теории и практики. Кишинев : Штиица, 1973. 258 с.

8. Паризька конвенція про охорону промислової власності від 20 березня 1883 рокy. URL:https: / / zakon.rada.gov.ua/ laws/show/995_123\#Text (Jama звернення: 14.07.2020).

9. Про авторське право та суміжні права : Закон України від 23 грудня 1993 року № 3792-XII. URL: https:// zakon.rada.gov.ua/laws / show/ 995_169\#Text (дата звернення: 14.07.2020).

10.Про охорону прав на винаходи і корисні моделі : Закон України від 15 грудня 1993 року № 3687-XII. URL: https://zakon.rada.gov.ua/laws/ show/3792-12\#Text (дата звернення: 14.07.2020)

11. Райгородский $H$. Наследование имущественных прав по советскому авторскому праву. Социалистическая законность. 1956. № 2. С.14.

12. Рябоконь Є.О. Спадкове правовідношення в иивільному праві : автореф. дис. канд. юрид. наук. Київ : Київський наи. ун-т ім. Т. Шевченка. 2002. 20 с.

13. Харитонова О.I. Правовідносини інтелектуальної власності, що виникають внаслідок створення результатів творчої діяльності (концептуальні засади) : монографія. Одеса : Фенікс, 2011. 346 с.

14. Цивільний кодекс України від 16.01.2003 № 435-IV. URL: http:// zakon2.rada.gov.ua / laws / show / 435-15 (дата звернення: 14.07.2020).

15. Чуйкова В.Ю. Правові питання спадкування за заповітом : автореф. дис. канд. юрид. наук: 12.00.03. Харків, 1999. 20 с.

16. Чурпіта Г.В. Право автора на збереження цілісності твору образотворчого мистецтва. Підприємництво, господарство і право. 2003. № 7. С. 24-27.

17. Шишка Р.Б. Немайнові права автора. Вісник Академії правових наук України. 2002. № 3. С. 110-121. 